A complete session was given to a discussion concerning museums in the Cornmonwealth and Overseas with especial reference to the training of curators. Dr. D. B. Harden, chairman, in opening the discussion, referred to the progress that had already been made with training schemes in South Africa and Canada and expressed the hope that an overseas secretary would be appointed at no distant date to deal with the furtherance of international relationships between the home country, the Dominions and other smaller countries within the Commonwealth. Subsequent speakers included professional museum staff from parts of Africa, Pakistan and Singapore. It was stated by Prof. P. L. Shinnie of the University of Ghana that countries which had recently achieved their independence would not be content with having their museums staffed by English people. On the other hand, Africans with good degrees would scarcely be willing to accept museum posts when there were far more attractive openings in the Civil Service. $\mathrm{He}$ felt that the training of technicians could be dealt with in Africa but that curators should have the benefit of a European tour of representative institutions. Dr. L. S. Russell, secretary of the Museums Association in Canada, stated that an inquiry had, contrary to the accepted idea, shown that the chief difficulty in that country was not geographical separation but diversity of subject-matter.

Another session, under the chairmanship of Dr. W. E. Swinton, was devoted to museum architecture. It was opened by Mr. Sheppard Fidler, city architect of Birmingham, who described in detail the reconstruction of the galleries which had been so severely bombed during the War. Dr. H. L. C. Jaffé, Amsterdam, dealt with the many building schemes which had taken place in Holland and several other speakers contributed to the discussion.
In proposing a resolution which deplored the continual negative attitude of H.M. Government towards granting assistance to local museums and art galleries, and urging that everything should be done to acquaint those in authority and others with the facts, Sir Mortimer Wheeler felt that the Standing Commission was an eminent body but of no service to provincial museums. He stressed the urgent need for analytical information and considered that a Royal Commission on the whole subject was long overdue. Government help on a modest scale was needed, and he felt an analogy with the successful University Grants Committee was sound and could be fruitful.

At the annual general meeting, Dr. W. E. Swinton, British Museum (Natural History), was elected president and Sir Philip Hendy and Prof. Lionel Robbins vice-presidents for the ensuing year.

A successful feature of the conference was the large number of working parties which had been arranged at the larger museums and art galleries in London. These were much appreciated by both the Dutch and British delegates and led to many useful discussions in which small groups benefited greatly from the expert knowledge of the staffs concerned.

Receptions were on a lavish scale and included an evening one at the National Gallery which was graced by the presence of Her Majesty Queen Elizabeth the Queen Mother, patron of the Museums Association, a spectacular reception at the Guildhall given by the Corporation of London and smaller groups at the Wellcome Historical Museum of Medical Science and the Iveagh Bequest, Kenwood. The annual dinner was held at the Goldsmiths' Hall and the conference concluded with field meetings at Brighton, Petworth House, Saltwood Castle and Canterbury, Cambridge and St. Albans. It was decided to hold the next conference in Worthing during June 15-20, 1959.

\title{
THE BACKGROUND TO SPECIALIST TECHNOLOGICAL EDUCATION
}

\author{
By DR. M. L. R. PETTERSSON \\ Brunel College of Technology, Acton, London, W.3
}

$\mathrm{H}$ OW does, how should, the content of a course for the diploma in technology differ from that of a traditional honours degree course? It is the present purpose to attempt, in part, to give an answer to this question. The tradition of technical education, often by apprenticeship, can be traced back to the earliest stages of human society. The educational tradition of scholarly book learning, on the other hand, has evolved only in the past 1 per cent of human existence. The medieval universities and schools took their character almost entirely from the scholarly tradition. Yet it is by a blending of these two kinds of activity that the flowering of modern science has arisen; to produce the change from the agricultural to the industrial stage of human society.

To what extent is present-day education adapted to the needs of our children, in contemporary industrial society? We have in Britain, comparatively, an extremely good educational system. But since society is developing with such rapidity, both recent reforms and further changes appear inevitable. Confining attention to grammar school and college education, the following five points are offered for consideration.

(1) At the Renaissance, attention to ancient writers was a progressive change. But to-day, whether in English, languages, history or the sciences, too little consideration is often given to the past ten, thirty and a hundred years.

(2) Though the medieval scholarly tradition of book learning has already been much blended with practical manual activities, most school and some college laboratories could do with ten times the costly equipment, space and technician assistance, to give fully effective courses.

(3) The medieval scholarly tradition is mainly of 'pure' studies. It is suggested that in the later years of nearly everyone's education there could well be a higher proportion of applied aspects, both those of use to the general citizen and those which are specifically vocational. This could make higher education 
both more interesting as well as a better preparation for later life.

(4) While the Renaissance, plus printing, greatly increased the store of written work available for study, the recent upsurge of science has increased our available scientific written knowledge and material equipments vastly more. Dr. D. J. Price, in Discovery of June 1956, gives evidence which suggests that our total scientific knowledge is roughly doubling every 10-15 years, and has been doing this for at least two centuries. The rate of increase is about a hundredfold per century; and thus, since the schooldays of Newton, scientific knowledge seems to have increased by something like a million-fold. This has resulted in $(a)$ the extended duration of science courses, and in $(b)$ a further specialization in ever narrower sectors of our total knowledge. The special degree course has been built on top of the General, and university entrance is now preceded by a stiff two or three years in the sixth form in schools. But since lecturers and examiners find it very difficult to drop out older points of detail when new data are incorporated into a subject, there is still often an unhealthy overload of factual material to be memorized, as the Science Masters' Association has recently pointed out. One suspects that the amount of work necessary for graduation, a century ago, may have been little or no more than the work necessary for three General Certificate of Education (Advanced Level) science passes to-day-and perhaps the high-school student deserves more public credit for his achievement.

(5) The enormous increase of modern scientific knowledge has necessitated progressive specialization of courses. But one result is that, for each student, a greater proportion of the sectors of modern knowledge remains neglected. On the other hand, in an industrial democracy, it is most desirable that a large proportion of citizens should be properly equipped with a balanced outlook based on all branches of scientific and other knowledge; with "a broad outlook and a sense of spiritual and human values" (Circular 323). Thus a case can be made for devoting some 10 per cent of each week of sixth-form and college time to achieving this end.

The above five points arise partly from the rapidity of scientific advance and partly from the character of earlier scholastic education. They may be summed up as suggesting a further shift of emphasis : (1) from old to new; (2) from book learning to practical; (3) from pure to applied, including vocational ; (4) from an encyclopædic to a more selective approach, and to still greater specialization of the main subject; but (5) towards developing, on the side, a balanced and integrated cultural background covering the whole range of modern knowledge.

Viewed in this kind of historical perspective, the real or potential virtues of the new courses for the Diploma in Technology are clearly apparent. The National Council for Technological Awards, which sponsors these courses, has given the teaching colleges considerable freedom in the design of syllabuses, and these are under constant review. Thus, while maintaining a serious academic coverage of principles, many older topics can be dropped out in favour of newer ones of contemporary relevance. The laboratory time of the eight terms at college is reinforced by four six-month periods of actual industrial employment; and the whole emphasis of the later years of the course is deliberately vocational and applied. In many places the importance of a selective rather than an encyclopædic approach is forcefully realized; while each course is at least as specialized as that for a special degree. In addition, there is an earnest groping towards a suitable development of non-vocational liberal studies, to occupy some 10 per cent of the time-table. The entrance requirement for a diploma in technology course is approximately the same as for a university, though National Certificates are recognized besides the General Certificate of Education. Some students are entered by industrial firms, while others come direct from school sixth forms. Most, though not all, diploma courses are conducted on the sandwich principle. Thus, in each of the four (or five) years, two terms at college are succeeded by six months in appropriate industrial employment; and it is expected that after the four years of scientifically and technologically up-to-date education and experience the average diploma holder will be at least as effective a member of his firm as the average graduate becomes after a further year or two of postgraduate training. Incidentally, the diploma qualification is now recognized as at least the equivalent of a degree by the Burnham Committee. Thus, it is also a route for the recruitment of younger school teachers, who will arrive at school with a much fuller understanding of contemporary life.

The annual intake of students to the diploma courses is at present 736 , and is rising rapidly. $1957-58$ is only the second year of normal enrolment, and in a few years the intake is likely to be several thousand. The courses are mainly conducted in the new colleges of advanced technology, and where there is a research tradition. The students attending come from all parts of the country. By last autumn the number of subjects for which courses had received the provisional approval of the National Council, at the different centres, was as follows:

Battersea, London
Birmingham
Northampton, London
Brunel, London
Chelsea, London
Northern, London
Woolwich, London
Borough, London
Loughborough
Cardiff
Kingston, Surrey
Wolverhampton

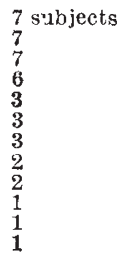

In a few cases these courses have not yet commenced, but on the other hand in some colleges, especially Battersea College, the courses are run in duplicatesandwich plus full-time.

In conclusion, it may be mentioned that the courses running last spring, numbering forty in all, had the following subject distribution:

Mechanical and production engineering
Electrical engineering
Applied chemistry, etc.
Physics
Setallurgy
Aeron:autical engineering
Chemical engineering
Mathematics
Applied biology
Civilengineering

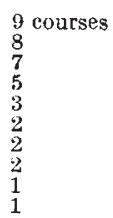

The engineering and other studies which have developed from the basic work done by the old flint knappers, bronze smiths and millwrights are well represented; but there is already one course, at Brunel College, dealing with the industrial aspects of living organisms. 